2007s-16

\title{
Electronics Production Upgrading: Is China Exceptional?
}

\author{
Ari Van Assche, Byron Gangnes
}

Série Scientifique
Scientific Series

Montréal

Août 2007

(C) 2007 Ari Van Assche, Byron Gangnes. Tous droits réservés. All rights reserved. Reproduction partielle permise avec citation du document source, incluant la notice (C).

Short sections may be quoted without explicit permission, if full credit, including (C) notice, is given to the source.
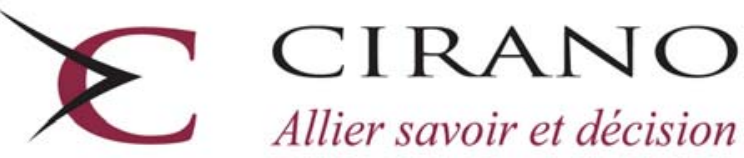

Allier savoir et décision

Centre interuniversitaire de recherche en analyse des organisations 


\section{CIRANO}

Le CIRANO est un organisme sans but lucratif constitué en vertu de la Loi des compagnies du Québec. Le financement de son infrastructure et de ses activités de recherche provient des cotisations de ses organisations-membres, d'une subvention d’infrastructure du Ministère du Développement économique et régional et de la Recherche, de même que des subventions et mandats obtenus par ses équipes de recherche.

CIRANO is a private non-profit organization incorporated under the Québec Companies Act. Its infrastructure and research activities are funded through fees paid by member organizations, an infrastructure grant from the Ministère du Développement économique et régional et de la Recherche, and grants and research mandates obtained by its research teams.

\section{Les partenaires du CIRANO}

\section{Partenaire majeur}

Ministère du Développement économique, de l’Innovation et de l’Exportation

\section{Partenaires corporatifs}

Alcan inc.

Banque de développement du Canada

Banque du Canada

Banque Laurentienne du Canada

Banque Nationale du Canada

Banque Royale du Canada

Banque Scotia

Bell Canada

BMO Groupe financier

Bourse de Montréal

Caisse de dépôt et placement du Québec

DMR Conseil

Fédération des caisses Desjardins du Québec

Gaz de France

Gaz Métro

Hydro-Québec

Industrie Canada

Investissements PSP

Ministère des Finances du Québec

Raymond Chabot Grant Thornton

State Street Global Advisors

Transat A.T.

Ville de Montréal

\section{Partenaires universitaires}

École Polytechnique de Montréal

HEC Montréal

McGill University

Université Concordia

Université de Montréal

Université de Sherbrooke

Université du Québec

Université du Québec à Montréal

Université Laval

Le CIRANO collabore avec de nombreux centres et chaires de recherche universitaires dont on peut consulter la liste sur son site web.

Les cahiers de la série scientifique (CS) visent à rendre accessibles des résultats de recherche effectuée au CIRANO afin de susciter échanges et commentaires. Ces cahiers sont écrits dans le style des publications scientifiques. Les idées et les opinions émises sont sous l'unique responsabilité des auteurs et ne représentent pas nécessairement les positions du CIRANO ou de ses partenaires.

This paper presents research carried out at CIRANO and aims at encouraging discussion and comment. The observations and viewpoints expressed are the sole responsibility of the authors. They do not necessarily represent positions of CIRANO or its partners.

ISSN 1198-8177 


\title{
Electronics Production Upgrading: Is China Exceptional?
}

\author{
Ari Van Assche, ${ }^{\dagger}$ Byron Gangnes ${ }^{\ddagger}$
}

\section{Résumé / Abstract}

Cette étude emploie une banque de données unique sur la production électronique mondiale pour évaluer la trajectoire de perfectionnement de la Chine dans le secteur électronique mondial. Contrairement aux études existantes, nous ne trouvons aucune évidence que les activités de production de la Chine dans le secteur électronique sont plus sophistiquées que ce à quoi on pourrait s'attrendre de son niveau de développement. En plus, nous trouvons peu d'évidence que la Chine perfectionne rapidement ses activités de production.

Mots clés : Chine, perfectionnement industriel, électronique.

In this paper, we make use of a unique world electronics production data set to assess China's upgrading trajectory in the global electronics industry. Contrary to existing studies, we find no evidence that China's electronics production activities are more sophisticated than one would expect from its level of development. We also find little evidence that China is rapidly upgrading into more sophisticated production activities.

Keywords: China, industrial upgrading, electronics.

Codes JEL : O10, O14, L63

\footnotetext{
* This paper benefited from comments received at the 18th CEA (UK) annual conference in Nottingham and the $41^{\text {st }}$ annual Canadian Economic Association meetings in Halifax. We would like to thank Nicolas Barbe for excellent research assistance and David Boileau for helpful discussions. Van Assche thanks the fonds québécois de la recherche sur la société et la culture (FQRSC) for financial support.

${ }^{\dagger}$ HEC Montréal, Department of International Business, 3000 Chemin de la C^ote-Sainte-Catherine, Montr'eal (Québec), Canada H3T2A7. Phone: (514)340-6043. Fax: (514)340-6987. E-mail: ari.van-assche@hec.ca. $\ddagger$ University of Hawaii at Manoa.
} 


\section{Introduction}

China's economy seems to be upgrading rapidly. Where fifteen years ago China was primarily an exporter of low-tech products such as apparel, toys and footwear, today it has become the world's largest exporter of electronics products (OECD, 2005). This has caused concern in the West that China is rapidly moving up the technology ladder and becoming increasingly competitive in areas of comparative advantage for Western economies.

A number of recent studies have used trade data to show that China indeed has become more sophisticated than one would expect given its level of development. Rodrik (2006) and Hausmann et al. (2007) develop a methodology to assess a country's position on the technology ladder by analyzing the composition of its export bundle. ${ }^{1}$ They posit that an export good is more sophisticated the higher the weighted average income of its exporting countries. This permits a ranking of export products according to their "implied productivity." They then use each country's export composition to estimate the degree of sophistication of its export bundle vis-à-vis the rest of the world. Rodrik (2006) and Hausmann et al. (2007) find that the bundle of goods that China exports is similar in sophistication to exports of countries with income levels three times higher than that of China, thus leading Rodrik (2006) to conclude that "China has somehow managed to latch on to advanced, high productivity products that one would not normally expect a poor, labor abundant country like China to produce, let alone export."

Using a similar logic, Schott (2006) has recently used Finger and Kreinin's (1979) export similarity index to demonstrate that China's exports are surprisingly similar to the export structure of OECD countries. This has led Schott (2006) to conclude that "China's export bundle increasingly overlaps with that of more developed countries, rendering it more sophisticated than countries with similar endowments."

The main shortcoming of these studies is that trade patterns can be a poor indicator of a country's set of comparative advantage goods (Baldone et al., 2006; Van Assche, 2006). International trade data are generally collected and reported as gross flows rather than as foreign value added, making it difficult to attribute the type of production activities that have taken place in an exporting country (Grossman and Rossi-Hansberg, 2006). Indeed, in a world with international production fragmentation and intermediate good trade, a country's exports do not necessarily reflect the embodied technology and relative endowments that have gone into the country's domestic

\footnotetext{
${ }^{1}$ Lall et al. (2006) have developed a similar approach, but did not focus on China.
} 
production activities, but may simply reflect the technology and factors of the countries from which it imports intermediate goods. To illustrate this, consider an export good $z$ that is produced through the assembly of inputs $x$ and $y$. In Figure 1, we depict two scenarios. In Scenario 1, the production of the inputs $x$ and $y$ and the assembly of product $z$ all occur at home. In Scenario 2, the inputs $x$ and $y$ are imported from abroad, while only the assembly occurs at home. Although the amount and type of production activities differ in the two scenarios, the export pattern is identical. This implies that export data will overestimate a country's production activities in industries with a large share of processing trade. ${ }^{2}$

Two features of China's export system suggest that its estimated sophistication level is likely to be biased upward more than other countries. First, China's foreign trade expansion in the last few decades is mainly due to a rise in processing exports. In 1986, processing exports accounted for only 18 percent of China's total exports, while by 2005 they had risen to more than 55 percent (Naughton, 2007). Second, the share of processing exports in total exports has consistently been higher in high-tech industries such as electronics than more traditional industries such as textiles, leather and shoes (Gaulier et al., 2005). These two characteristics suggest that the existing literature's result that China's export bundle is relatively more sophisticated than one would expect from the country's level of economic development might be a statistical mirage.

In this paper, we provide an alternative estimate of China's position on the global technology ladder by making use of a unique data set of world electronics production compiled by Reed Electronics Research. ${ }^{3}$ Contrary to existing studies, we find no evidence that China's electronics production activities are more sophisticated than one would expect from its level of development. We also find little evidence that China is rapidly upgrading into more sophisticated production activities.

\footnotetext{
${ }^{2}$ Processing trade encompasses imports of goods to be assembled or transformed in China and re-exported, within international assembly and subcontracting operations. These imported inputs are exempted from tariffs.

${ }^{3}$ Production data could be subject to the same difficulty in identifying value added as opposed to the value of gross sales, which could in some cases, "amount to little more than assembly of imported piece-parts and sub-assemblies." The problem is likely smaller than for export values, however, since goods are counted in production only when "value is added in the assembly process and the finished article can be classified under a different SIC (Standard Industrial Classification) from those of its components." (Reed Electronics Research, 2007.)
} 


\section{Data and Methods}

The Reed Electronics Production Data Set (REP) measures a country's domestic production by electronics subcategories for 51 countries. The coverage and degree of disaggregation in the REP varies between countries, but we have been able to extract a consistent panel for 13 electronics subcategories from 1992 to 2005 (See Table 1 for the list of product subcategories). The subcategories range from computers and peripherals to medical equipment, audio and video equipment, semiconductor parts, and even electronic clocks and watches.

\section{[Table 1 about here]}

In Table 2, we present summary statistics from the REP data set. The table clearly identifies the emergence of China (and the rest of developing East Asia) as a dominant player in the global electronics industry. China's electronics production has grown at a remarkable rate of 24.8 percent between 1992 and 2005. As a result, China's share of world electronics production has risen from 1.9 percent in 1992 to 18.4 percent in 2005. With a value of production of 260.1 billion U.S. dollars, it has surpassed that of the European Union and Japan, just lagging behind the U.S. electronics production value.

\section{[Table 2 about here]}

The rapid rise in China's share of global electronics production, however, does not necessarily mean that China is upgrading technologically. The electronics sector is a highly heterogeneous industry that consists of production activities that vary greatly in their sophistication levels. If China is primarily specialized in production activities with low sophistication levels, then China's rise in the global electronics industry does not necessarily go handin-hand with technological upgrading. To analyze China's position on the global technological ladder, it is therefore necessary to take into account the composition of production activities that take place within its electronics industry. 
Revealed comparative advantage (RCA) indices are often used to measure patterns of specialization in trade. ${ }^{4}$ We can compute a similar index to measure patterns of production specialization. Let $x_{i, c}$ denote the production value of electronics subcategory $i$ in country $c$, then $X_{c}=\sum_{i} x_{i, c}$ equals country $c$ 's total electronics production value. Then the production intensity index (PII) is given by:

$$
P I I_{i, c}=\left(\frac{x_{i, c}}{X_{c}}\right) /\left(\frac{\sum_{c} x_{i, c}}{\sum_{c} X_{c}}\right) .
$$

Values greater than one indicate that the country has a greater share of its electronics production in the product subcategory than world producers as a whole.

Table 3 presents the production intensity indices based on production data for each electronics subcategory for China, the ASEAN-4 (Indonesia, Malaysia, the Philippines and Thailand), the Newly Industrialized Economies (NIEs: Hong Kong, Singapore, South Korea and Taiwan), Japan, the United States and the EU-15. Average indices are reported for both the 1992-1994 and 2003-2005 periods. The production specialization patterns vary greatly across countries. In 2003-2005, for example, China was particularly specialized in the electronics sub-categories audio equipment, electronic data processing (EDP), other components and video equipment. The United States, on the other hand, was specialized in the production of very different subcategories including $x$-ray $\&$ medical equipment, control and instrumentation, office equipment and radio communications $\& 6$ radar.

\section{[Table 3 about here]}

Even if China begins at a lower echelon of the global technological ladder, it can upgrade by gradually specializing in more sophisticated production activities. And in fact, a comparison of China's production intensity indices for 1992-1994 and 2003-2005 shows that China's specialization pattern has changed over the past two decades. Specifically, its electronics industry has

\footnotetext{
${ }^{4}$ The revealed comparative advantage (RCA) index (Balassa 1965), a measure of trade specialization, is generally calculated as a country $c$ 's share of world exports of a good $i$ divided by its share of total world exports: $R C A=\left(\frac{e x_{i, c}}{E X_{c}}\right) /\left(\frac{\sum_{c} e x_{i, c}}{\sum_{c} E X_{c}}\right)$. Values greater than one indicate that the country has a greater share of its exports in the product category than world exporters as a whole. In this paper, we use the same methodology, but use production data instead of export data.
} 
become more specialized in sub-categories electronic data processing and radio communications $\&$ radar, while becoming less specialized in personal consumer electronics and audio equipment among others (see Table 3).

To estimate China's position on the technology ladder as well as its upgrading trajectory in the electronics industry, we use a methodology similar to Rodrik (2006) and Hausmann et al. (2006). In a first step, we estimate the level of technological sophistication of a product as the weightedaverage income of its producers. The rationale behind this is that, in the absence of trade interventions, richer countries generally will have characteristics that provide a comparative advantage in more-advanced industries. These characteristics may include high capital abundance, the embodiment of higher-level technology and better institutions. Let $Y_{c}$ represent country c's per-capita GDP in current prices, with the other symbols as defined above. Then the level of product sophistication $S$ for good $i$ is given by

$$
S_{i}=\sum_{c} \frac{x_{i, c} / X_{c}}{\sum_{c}\left(x_{i, c} / X_{c}\right)} Y_{c}
$$

The numerator of the weighting expression is the share of product $i$ in overall production for a country. The denominator gives the sum of these shares across all countries. Therefore, the index is a weighted average of national incomes, where the weights reflect patterns of relative specialization in that good. It is straightforward to rearrange equation (2) so that a country's weight is a function of all countries' production intensity indices:

$$
S_{i}=\sum_{c} \omega_{i, c} Y_{c}
$$

where

$$
\omega_{i, c}=\frac{\mathrm{PII}_{i, c}}{\sum_{c} \mathrm{PII}_{i, c}} .
$$

The value of sophistication index, $S_{i}$, summarizes the average income of countries specialized in the production of good $i$. Note that there are two reasons why a good's sophistication index may increase. First, it may increase because rich countries increase their specialization in the production of good $i$. Second, it may increase because the countries that are specialized in good $i$ get relatively richer than the rest of the world.

Once the sophistication index has been estimated for all goods $i$, one can calculate a country's technology index $C T I$ as the weighted average of the sophistication levels of the products that it produces:

$$
C T I_{c}=\sum_{i} \theta_{i, c} S_{i} .
$$


where a product's weight $\theta_{i, c}$ equals the share of good $i$ in country $c$ 's total electronics output:

$$
\theta_{i, c}=\frac{x_{i, c}}{X_{c}}
$$

\section{$3 \quad$ Results}

In this Section, we present the results in three parts. In subsection 3.1, we discuss how electronics subcategories are ranked in terms of their degree of sophistication and how this has changed over time. In subsection 3.2, we then analyze how China's estimated technology index compares to other countries. Finally, in subsection 3.3, we compare China's technology index to its level of development.

\subsection{Product Sophistication Index}

In Table 4 we present the average sophistication indices for the various electronics subcategories in 1992-1994 and 2003-2005 respectively. We can make a couple of observations concerning the sophistication rankings. First, it might seem surprising that personal consumer electronics is ranked as the most sophisticated electronics subcategory, since it primarily accounts for items such as electronics clocks and watches. This can be explained by the fact that the world's richest country - Switzerland - produces almost a third of the total value of personal consumer electronics.

Second, the ranking of electronics subcategories has remained fairly stable across time. The three most sophisticated subcategories are consistently personal consumer electronics, x-ray $\& 5$ medical equipment and control $\&$ instrumentation, while the four least sophisticated products are video equipment, audio equipment, office equipment and industrial equipment.

Third, there is one electronics subcategory that has seen a dramatic change in ranking: electronic data processing (EDP). In 1992-1994 it was ranked as the 4th most sophisticated product, while in 2003-2005 it had dropped to 9th place. This drop in ranking is because developed countries in the last two decades have significantly reduced their specialization in $E D P$, while developing countries have increased their specialization. Indeed, the PII index for EDP of developing countries including China, the ASEAN-4 countries, Mexico and a number of Eastern European countries all increased significantly between 1992 and 2005. At the same time, many EU-15 countries, Japan, the United States and Canada have reduced their specialization in EDP. This trend can be attributed to the large-scale offshoring of EDP 
assembly plants by multinational firms to developing countries primarily in East Asia, made possible by changes in technology and the economic environment that facilitated the vertical fragmentation of computer production (Dedrick and Kraemer, 1998; Bonham et al., 2006).

\section{[Table 4 about here]}

\subsection{Country Technology Index}

In Table 5, we present the Country Technology Index (CTI) in the global electronics industry. A number of observations stand out. First, Switzerland and the Scandinavian countries Denmark, Norway, Finland and Sweden have the highest technology indices in 2003-2005 due to their high specialization in the most sophisticated subcategories personal consumer electronics, $x$-ray $\& 3$ medical equipment, control $\&$ instrumentation and radio $\mathcal{E}$ radar communications. In Switzerland, for example, almost a third of its electronics production in 2005 was in personal consumer electronics and a quarter of its electronics production was in control $\mathscr{E}$ instrumentation. Two thirds of Finland's electronics production in 2005 was in radio 83 radar communications, chiefly cellular phones.

\section{[Table 5 about here]}

The very high ranking of Saudi Arabia and Puerto Rico may be surprising. For Saudi Arabia, this is due to their high specialization in radio $\mathcal{E}_{3}$ radar communications and $x$-ray $\&$ medical equipment. ${ }^{5}$ For Puerto Rico, this is due to the fact that 44.1 percent of its electronics production value in 2005 was $x$-ray $\& 5$ medical equipment.

There are several countries that have made large moves up or down the rankings since the 1992-1994 period. Finland's move up from 15 th place to 4th place in the rankings reflects a doubling of its degree of specialization in radio communications with the cellular phone boom. Austria's jump from 44th to 20th place reflects a shift from low-sophistication audio and video

\footnotetext{
${ }^{5}$ The fact that Saudi Arabia's overall trade is dominated by oil exports does not affect the present analysis, which focuses only on the country's pattern of specialization within the electronics sector.
} 
equipment to higher-sophistication areas including control and instrumentation, x-ray and medical equipment and active components and passive components. Hong Kong's (surprising?) drop from 9th to 26th place reflects a rise in relative production shares for office equipment, industrial equipment and audio equipment. In the case of Ireland, it appears that the marked decline in ranking is associated with the drop in the estimated product sophistication of electronic data processing, in which Ireland is particularly heavily specialized.

Notably, our analysis provides little evidence that China has rapidly moved up the global technological ladder. While China was ranked 42nd in 1992-1994, it has only moved up to the 39th position in 2003-2005.

\subsection{CTI vs. Level of Development}

The primary question we want to address is whether the sophistication of China's electronics production is unusually high given its level of economic development. As we discussed above, several authors have argued that this is the case for overall Chinese production based on an analysis of export data. Does this result hold up when electronics production data are considered? The answer is a resounding "no".

In Figure 2, we show the scatter plot of CTI against per-capita GDP in 2003-2005. Similar to the export analysis of Rodrik (2006) and Hausmann et al. (2007), we find that there is a positive correlation (the correlation coefficient is 0.64 ). Richer countries tend to have higher country technology index values. ${ }^{6}$ However, unlike these authors, we do not find that China is a positive outlier. Rather, we find that China lies dead on the regression line, implying that we find no empirical evidence that China's level of technological sophistication in electronics is higher than one would expect for its level of development. ${ }^{7}$

\section{[Figure 2 about here]}

\footnotetext{
${ }^{6}$ As noted by Hausmann et al. (2007), the positive relationship between CTI and percapita GDP is partly by construction, since a commodity's sophistication is determined by the per-capita income of countries that are important producers of the good. However, this accounts for only a limited part of the positive correlation.
} 


\section{Conclusion}

In this paper, we have made use of a unique world electronics production data set to assess whether China's electronics industry is more sophisticated than one would expect from its level of development. Contrary to existing studies, we find no evidence of this, nor do we find evidence that China is rapidly upgrading into more sophisticated electronics production activities.

There are admittedly some strong assumptions embedded in this analysisassumptions common to this literature. While it is plausible that income levels of producing countries may proxy for technology level, this is clearly imperfect. The mapping from production location to product sophistication is also potentially problematic. For example, whether a part is produced locally or imported from a lower-wage country may have as much to do with whether a final good can be easily modularized as it does with the technological sophistication of the underlying production process (Van Assche, forthcoming). It would be useful to have more sophisticated measures of product sophistication based on factor endowments and measurable productivity.

The idea of using income levels and specialization patterns to evaluate productivity levels is an appealing one. But if one wants to take this seriously, one must acknowledge the fundamental shortcoming of gross international trade data, which may tell us little about actual value added. Our results based on production data for electronics provide a striking contrast to the earlier broad trade-based results and challenge the common assertion that China is a positive outlier in the sophistication of its production. 


\section{References}

[1] Balassa, B. (1965) "Trade Liberalisation and Revealed Comparative Advantage", The Manchester School of Economic and Social Studies, 33, pp. 99-123.

[2] Baldone, S.; Sdogati, F.; Tajoli, L. (2006) "On Some Effects of International Fragmentation of Production on Comparative Advantages, Trade Flows, and the Income of Countries," CESPRI Working Paper No. 187.

[3] Bonham, C.; Gangnes, B.; Van Assche, A. (2007) "Fragmentation and East Asia's Information Technology Trade," Applied Economics, 39:2, pp. $215-228$.

[4] Dedrick, J.; Kraemer, K., 1998. Asia's Computer Challenge: Threat or Opportunity for the United States and the World? Oxford: Oxford University Press.

[5] Finger, J.; Kreinin, M. (1979). "A Measure of Export Similarity and Its Possible Uses." Economic Journal 89, pp. 905-912.

[6] Gaulier, G.; Lemoine, F.; Unal-Kesenci, D. (2005). "China's Integration in East Asia: Production Sharing, FDI and High-Tech Trade," CEPII Working Paper No. 2005-09.

[7] Grossman, G.; Rossi-Hansberg, E. (2006). "Trading Tasks: A Simple Theory of Offshoring." National Bureau of Economic Research Working Paper No. 12721.

[8] Hausmann, R; Hwang, J.; Rodrik, D. (2007). "What You Export Matters." Journal of Economic Growth, 12:1, pp. 1-25.

[9] Lall, S.; Weiss, J.; Zhang, J. (2006). "The Sophistication of Exports: A New Trade Measure," World Development 34:2, pp. 222-237.

[10] Naughton, B. (2007). The Chinese Economy: Transitions and Growth. Cambridge, MIT Press.

[11] OECD (2005). "OECD finds that China is biggest exporter of Information Technology Goods in 2004, surpassing US and EU," www.oecd.org/document/8/0,2340,en_2825_495656_35833096_1_1_1_1,00.html.

[12] Reed Electronics Research (2007). "Guide to the Interpretation of the Statistics." Mimeo. 
[13] Rodrik, D. (2006). "What's So Special about China's Exports?" China and the World Economy 14:5, pp. 1-19.

[14] Schott, P. (2006). "The Relative Sophistication of Chinese Exports." NBER Working Paper 12173.

[15] Van Assche, A. (2006). "China's Electronics Exports: Just A Standard Trade Theory Case", Policy Options 27:6. 79-82.

[16] Van Assche, A. (forthcoming). "Modularity and the Organization of International Production" Japan and the World Economy. 


\section{Table 1: Product categories}

\begin{tabular}{lll} 
Mnemonic & Category & Type of Products \\
\hline EDP & Electronic data processing & Computers, peripherals \\
OFF & Office equipment & Photocopiers, electronic calculators \\
CON & Control and instrumentation & Measuring instruments, control systems \\
XME & X-ray and medical equipment & X-ray equipment, electromedical equipment \\
IND & Industrial equipment & Traffic signaling, security and fire alarms \\
COM & Radio communications and radar & Mobile radio telephones, pagers \\
TEL & Telecommunications & Telephones, fax, answering machines \\
VID & Video equipment & Television, video camera, DVD player \\
AUD & Audio equipment & Portable audio, car audio, CD player \\
PCE & Personal consumer equipment & Electronic clocks, electronic watches \\
ACT & Active components & Integrated circuits, diodes, transistors \\
PAS & Passive components & printed circuit boards, relays, switches \\
OTH & Other components & Microphones, loudspeakers, amplifiers \\
\hline
\end{tabular}

Source: Reed Yearbook of World Electronics Data 


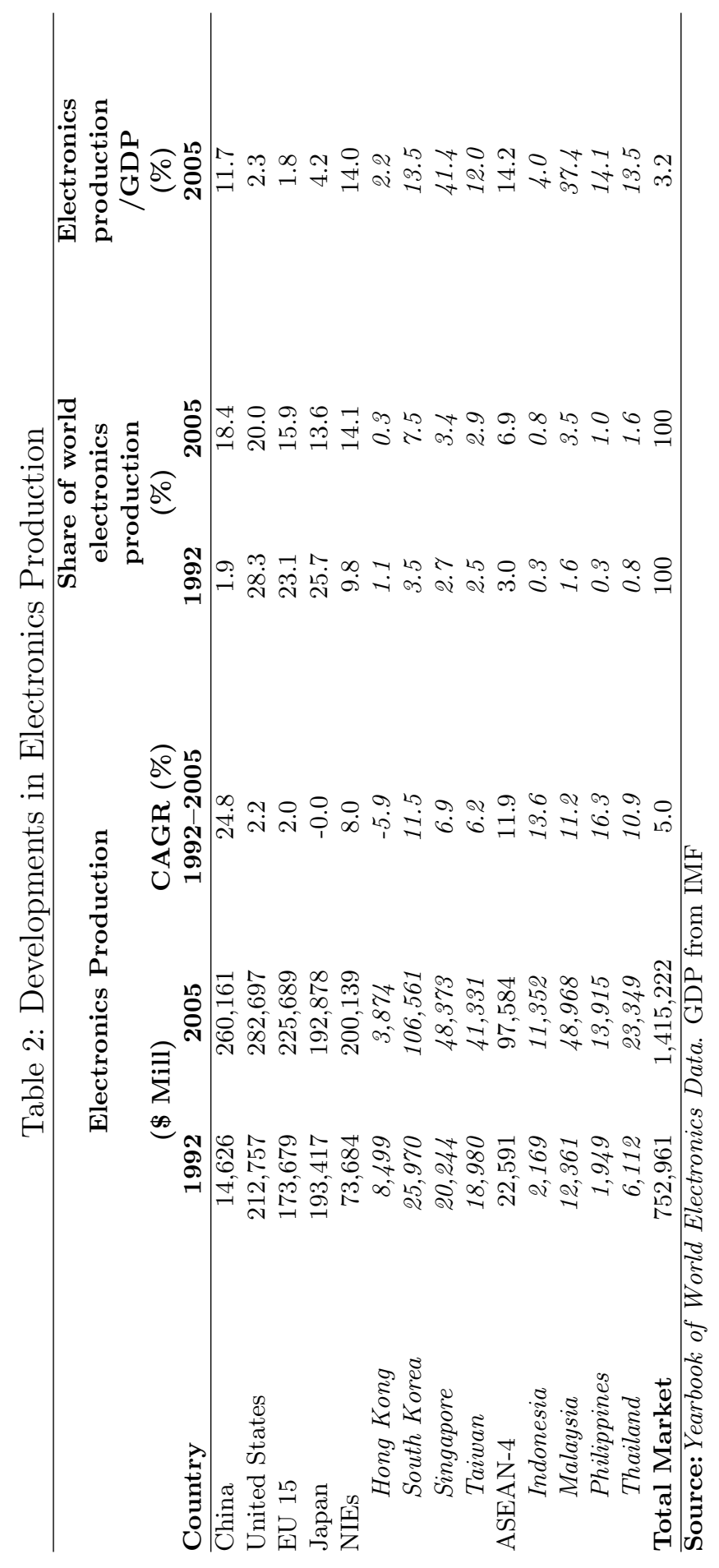




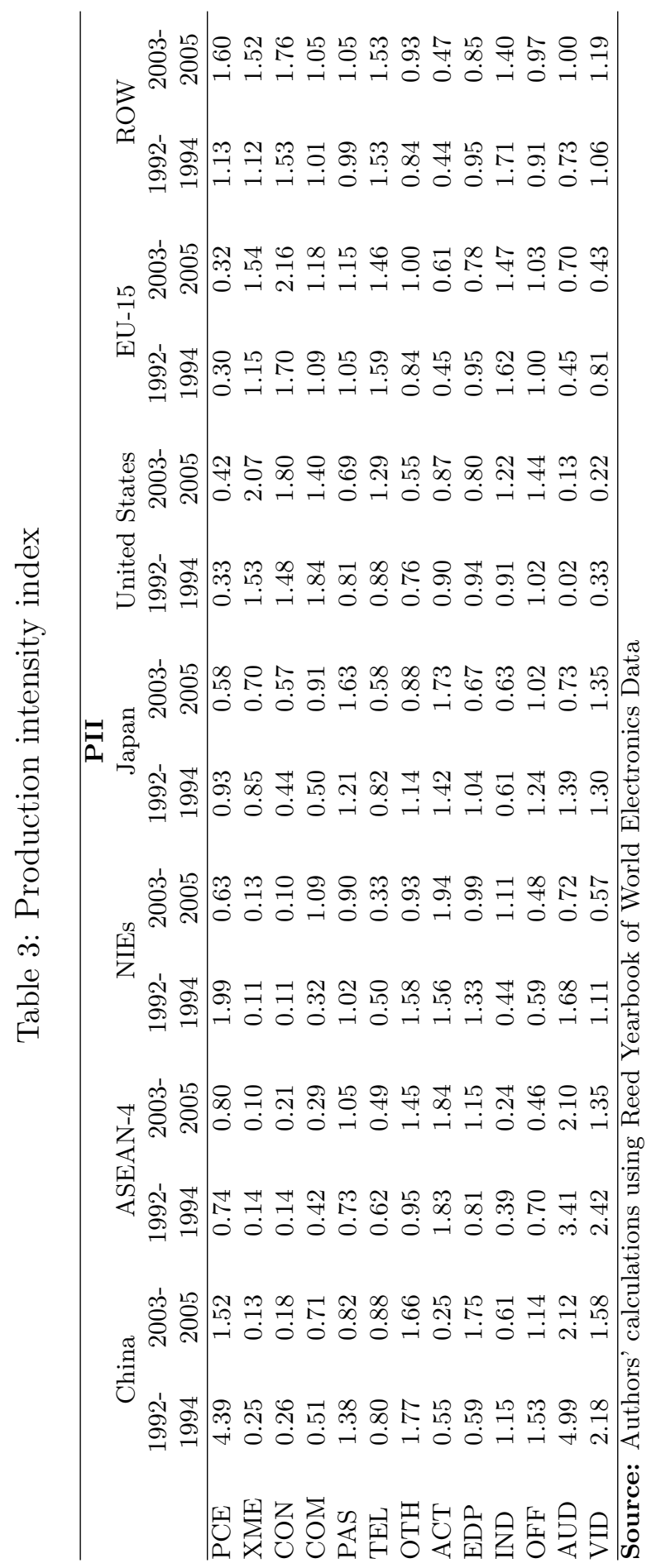


Table 4: Product sophistication index

\begin{tabular}{lcccc}
\hline & \multicolumn{2}{c}{$\mathbf{1 9 9 2 - 1 9 9 4}$} & \multicolumn{2}{c}{ 2003-2005 } \\
& Index & Ranking & Index & Ranking \\
\hline PCE & 17482 & $\mathbf{1}$ & 26722 & $\mathbf{1}$ \\
XME & 15133 & $\mathbf{2}$ & 25704 & $\mathbf{2}$ \\
CON & 15025 & $\mathbf{3}$ & 25388 & $\mathbf{4}$ \\
COM & 12791 & $\mathbf{5}$ & 21578 & $\mathbf{5}$ \\
PAS & 11992 & $\mathbf{8}$ & 18616 & $\mathbf{6}$ \\
TEL & 12343 & $\mathbf{7}$ & 18578 & $\mathbf{8}$ \\
OTH & 12690 & $\mathbf{6}$ & 18278 & $\mathbf{9}$ \\
ACT & 10740 & $\mathbf{9}$ & 17751 & $\mathbf{1 0}$ \\
EDP & 12897 & $\mathbf{4}$ & 17306 & $\mathbf{1 1}$ \\
IND & 9814 & $\mathbf{1 1}$ & 17046 & $\mathbf{1 2}$ \\
OFF & 10478 & $\mathbf{1 0}$ & 16007 & $\mathbf{1 3}$ \\
AUD & 7294 & $\mathbf{1 2}$ & 11150 & 8315 \\
VID & 6952 & $\mathbf{1 3}$ & &
\end{tabular}

Source: Authors' calculations using Reed Yearbook of World Electronics Data

SCENARIO 1

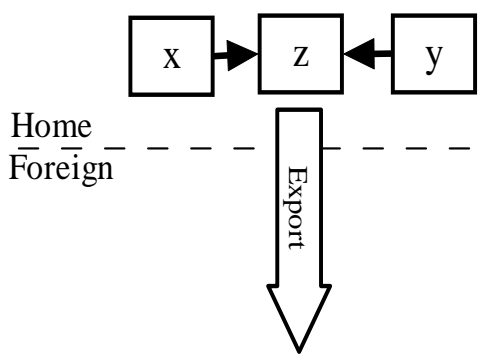

SCENARIO 2

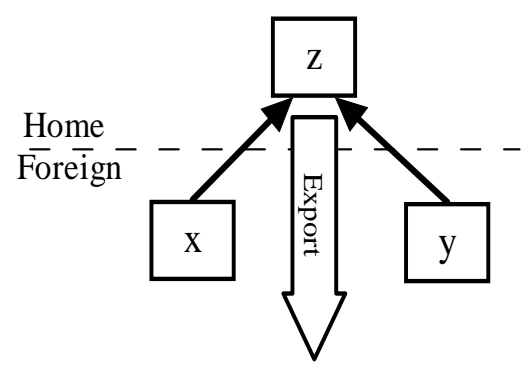

Figure 1: Ordinary versus processing trade. 
Table 5: Country technology index (rankings)

\begin{tabular}{|c|c|c|c|}
\hline Rank in $2003-2005$ & 1992-1994 & $1998-2000$ & $2003-2005$ \\
\hline Switzerland & 1 & 1 & 1 \\
\hline Denmark & 5 & 6 & 2 \\
\hline Norway & 4 & 4 & 3 \\
\hline Finland & 15 & 3 & 4 \\
\hline Sweden & 7 & 2 & 8 \\
\hline Saudi Arabia & 3 & 17 & 6 \\
\hline Puerto Rico & 8 & 25 & 7 \\
\hline Netherlands & 6 & 15 & 8 \\
\hline Germany & 17 & 7 & 9 \\
\hline Croatia & 12 & 11 & 10 \\
\hline Canada & 11 & 14 & 11 \\
\hline New Zealand & 2 & 5 & 12 \\
\hline United States & 13 & 8 & 13 \\
\hline Ukraine & 47 & 13 & 14 \\
\hline Australia & 16 & 9 & 15 \\
\hline Italy & 14 & 18 & 16 \\
\hline France & 20 & 12 & 17 \\
\hline Israel & 18 & 10 & 18 \\
\hline Bulgaria & 28 & 32 & 19 \\
\hline Austria & 44 & 36 & 20 \\
\hline United Kingdom & 19 & 20 & 21 \\
\hline Greece & 36 & 29 & 22 \\
\hline Slovenia & 21 & 24 & 23 \\
\hline Venezuela & 22 & 21 & 24 \\
\hline Romania & 34 & 19 & 25 \\
\hline Hong Kong & 9 & 16 & 26 \\
\hline Ireland & 10 & 22 & 27 \\
\hline Belgium & 26 & 37 & 28 \\
\hline South Korea & 43 & 23 & 29 \\
\hline South Africa & 33 & 34 & 30 \\
\hline Japan & 29 & 28 & 31 \\
\hline Philippines & 38 & 26 & 32 \\
\hline Taiwan & 24 & 30 & 33 \\
\hline Singapore & 27 & 31 & 34 \\
\hline Czech Rep. & 25 & 33 & 35 \\
\hline Russia & 41 & 35 & 36 \\
\hline Brazil & 32 & 38 & 37 \\
\hline Hungary & 23 & 46 & 38 \\
\hline China & 42 & 40 & 39 \\
\hline Malaysia & 49 & 41 & 40 \\
\hline Thailand & 37 & 39 & 41 \\
\hline Slovakia & 40 & 27 & 42 \\
\hline Spain & 31 & 43 & 43 \\
\hline India & 35 & 45 & 44 \\
\hline Portugal & 39 & 49 & 45 \\
\hline Vietnam & 51 & 48 & 46 \\
\hline Indonesia & 48 & 44 & 47 \\
\hline Poland & 30 & 42 & 48 \\
\hline Egypt & 45 & 50 & 49 \\
\hline Mexico & 46 & 47 & 50 \\
\hline Turkey & 50 & 51 & 51 \\
\hline
\end{tabular}

Source: Authors' calculations using Reed Yearbook of World Electronics Data 


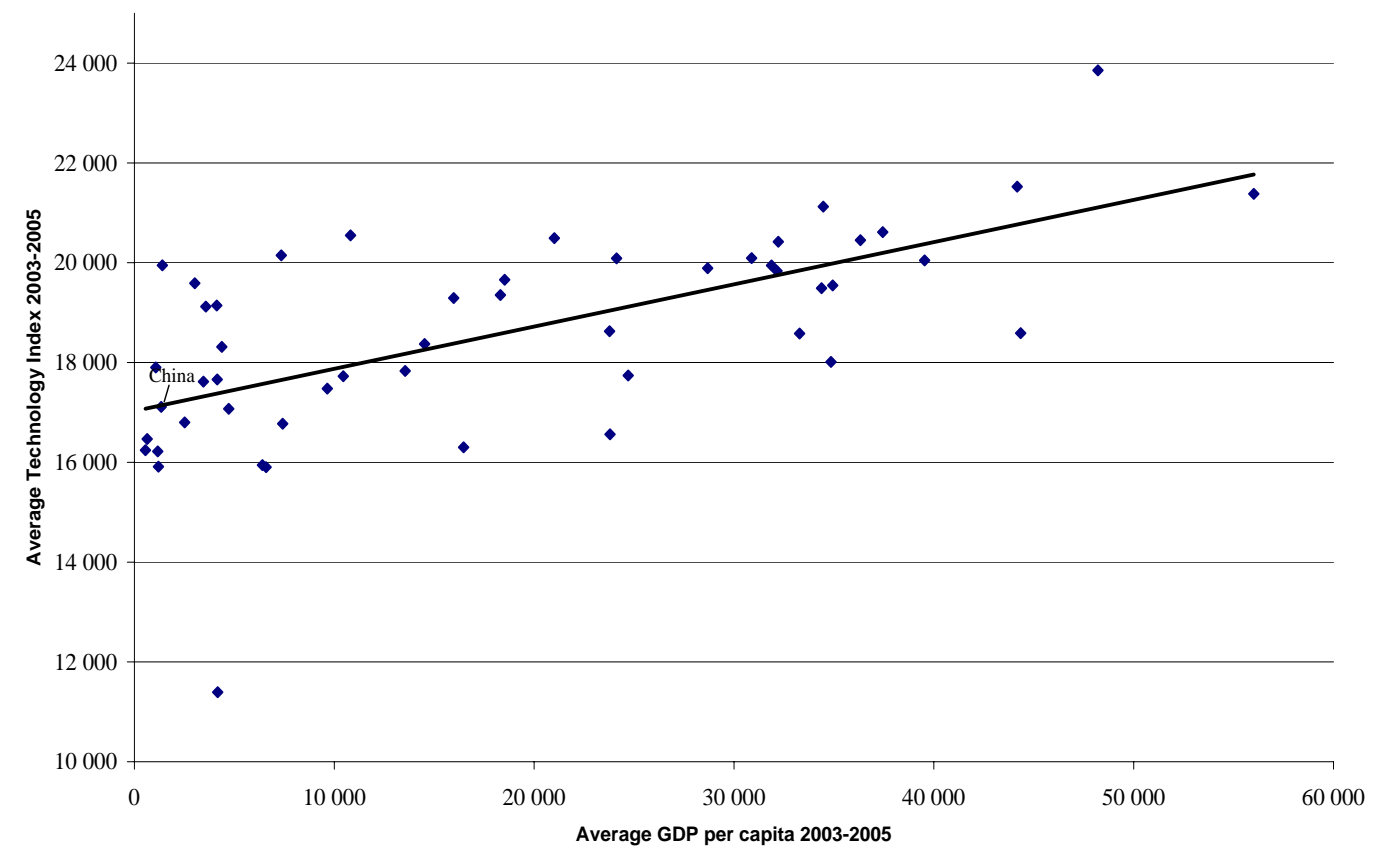

Figure 2: CTI versus GDP per capita. 